\title{
African Green Monkey
}

National Cancer Institute

\section{Source}

National Cancer Institute. African Green Monkey. NCI Thesaurus. Code C76360.

A medium-sized diurnal primate that is omnivorous, Chlorocebus sabaeus has a life span of 10 years in the wild and 25 years in captivity. The African green monkey has been in use in scientific research since the 1950s and its tissues are used to produce vaccines for polio and smallpox. Additionally Vero cells, an African green monkey kidney epithelial cell line, are widely used in immunology and infectious disease research. 